\title{
Physicochemical properties of milk fat from three breeds of cows during summer and winter feeding
}

\author{
JOANNA BARŁOWSKA ${ }^{1}$, TOMASZ GRODZICKI ${ }^{1}$, BARBARA TOPYŁA ${ }^{1}$ and ZYGMUNT \\ LITWIŃCZUK²
}

'Department of Commodity Science and Processing of Animal Raw Materials, ${ }^{2}$ Department of Cattle Breeding, University of Life Sciences, Lublin, Poland

\section{Abstract}

The investigations included total 515 milk samples which were collected from 309 cows of the main dairy cows' breeds used in Poland, i.e. Polish Holstein-Friesian Black-White variety $(n=150)$, Polish Holstein-Friesian Red-White variety $(n=77)$ and Simmental $(n=82)$. There was determined a content of fat, protein and dry matter, a share of fat globules ranging in size, i.e. $<6 \mu \mathrm{m}, 6-10 \mu \mathrm{m}$ and $>10 \mu \mathrm{m}$ as well as a fatty acids profile. It was shown that milk gained from Holstein-Friesian cows was characterized with a higher level of fat dispersion (over $70 \%$ globules of $<6 \mu \mathrm{m}$ diameter and a higher percentage of short- and long-chain fatty acids (ca. $19 \%$ ). The Simmentalers' milk had a higher protein: fat ratio (about 0.89), a lower fat dispersion level $(8.21 \%$ globules of $>10 \mu \mathrm{m}$ diameter) and the highest share of the polyunsaturated fatty acids (3.28\%). Cows nutrition included pasture forage during summer (independently on the breed) had a significant influence $(P \leq 0.01)$ on increased polyunsaturated fatty acids percentage (mean by $0.51 \%$ ). The winter milk, however, showed a significantly higher content of dry matter, fat and protein as well as a higher share of big-sized milk globules.

Keywords: dairy cattle, breeds, milk composition, fat globules, fatty acid, feeding season

\section{Zusammenfassung}

\section{Physiochemische Milchfetteigenschaften dreier Rinderrassen bei Sommer- und Winterfütterung}

Von 309 Milchkühen der Rassen Holstein Friesian ( $n=150)$, Rotbunte Holstein Friesian $(n=77)$ und Simmentaler ( $n=82$ ) wurden an Hand von 515 Milchproben der Fett-, Eiweiß- und Trockensubstanzgehalt sowie die Größe der Fettkügelchen $(<6 \mu \mathrm{m}, 6-10 \mu \mathrm{m}$ und $>10 \mu \mathrm{m})$ und das Fettsäureprofil bestimmt. Milch der Holstein Friesian wies einen höheren Dispersionsgrad der Fettkügelchen (über $70 \%<6 \mu \mathrm{m}$ ) und einen höheren Anteil kurz- und mittelkettiger Fettsäuren auf. Simmemtaler zeigten ein höheres Eiweiß:Fett-Verhältnis $(1: 0,89)$, ein niedrigeren Dispersionsgrad $(8,21 \%>10 \mu \mathrm{m})$ und mit 8,28\% den höchsten Anteil ungesättigter Fettsäuren. Unabhängig von der Rasse wurde durch die Grünfütterung im Sommer signifikant der Anteil ungesättigter Fettsäuren erhöht. Die Wintermilch war durch den höheren Trockenmasse-, Fettund Eiweißanteil sowie einen höheren Anteil größerer Fettkügelchen charakterisiert.

Schlüsselwörter: Milchrind, Rassen, Milchzusammensetzung, Fettkügelchen, Fettsäuren, Futtersaison 


\section{Introduction}

Fat is the second milk constituent (after protein) that determines milk nutritional value and its technological usefulness. It is a main energy component of milk and in human diet it is characterized with the highest digestibility among the fats of animal origin. Importance of milk fat is connected with a broad spectrum of fatty acids contained (ca. 400-500), not found in other fats (JENSEN 2002, REKLEWSKA and BERNATOWICZ 2003, PARODI 2004). A unique characteristic of cow milk fat is the presence of short- and medium-chain fatty acids (mean about 14\%) that are an available source of energy and do not deposits in human adipose tissue as the long-chain ones do (ŻEGARSKA 1998, PARODI 2004). Besides, fat milk contains polyunsaturated fatty acids (3-4.5\%), in that a conjugated linoleic acid (2\%) which currently arises an increased concern. Conjugated linoleic acid shows numerous specific functional properties, e.g. it prevents obesity, exerts antiatherogenic and anticancer effect as well as stimulates the immune system (PARK et al. 1997, SEIFERT et al. 1997, PFEUFFER 2001, BANNI et al. 2002).

A fat dispersion state decides about its availability and determines the quality of some dairy products. Size of fat globules ranges from 0.1 up to $20 \mu \mathrm{m}$ (MICHALSKI et al. 2002, MICHALSKI and JANUEL 2006). KOZIKOWSKI and PRZYBYŁOWICZ (1994) hold that higher comminution of globules ensures more effective fat digestibility. According to MICHALSKI et al. $(2002,2003,2004)$ fat globules size is of primary importance for cheese quality. At the soft cheese making, the better qualitative parameters are obtained when milk contains more small-sized fat globules, whereas producing hard cheeses the bigger milk fat globules should prevail. Hard cheese binds less water so it is more compact and firm and over its ripening period the proteolysis processes proceed faster.

GOUDEDRANCHE et al. (2000) state that at butter production it is also more advantageous to use milk abundant with big-sized fat globules as they have twice less of the biological membrane material and so less cholesterol gets into butter. Such butter is more yellow, of a softer texture (more unsaturated fatty acids) and better spreading. The protective membranes of big fat globules are broken easier so the churning process proceeds quicker.

Numerous research works indicate that the fat milk dispersion state along with the acids contributing to it, depends on a cow breed (LAWLESS et al. 1999, BARŁOWSKA et al. 2006a, 2006b, CARROLL et al. 2006), a production season and animals nutrition (REKLEWSKI 2000, PALMQUIST et al. 1993, MICHALSKI et al. 2004, WALISIEWICZ-NIEDBALSKA et al. 2004, BARŁOWSKA and LITWIŃCZUK 2006, CARROLL et al. 2006).

The aim of the present work was to compare a fat dispersion state and a fatty acids profile in the milk gained in summer and winter season from three breeds of dairy cows in Poland.

\section{Material and methods}

The investigations included total 515 milk samples which were collected from 309 cows of the main dairy cows' breeds used in Poland, i.e. Polish Holstein-Friesian Black-White variety $(n=150)$, Polish Holstein-Friesian Red-White variety $(n=77)$ and Simmental $(n=82)$. Each of cows' breed were maintained in another farm. Those farms were the loose 
cowsheds without straw where cows were milked twice (in the milking hall). The controlled animals' reproduction (artificial insemination) was led in the all farms. The samples were collected individually from cows chosen to the investigations, i.e. being between 3 and 5 month of lactation in the day of sample taking.

In each farm the milk samples were collected from the same animals twice, i.e. in a winter and summer season, what was connected with their different nourishment. The basis of alimentary dose composed a hay silage and silage from maize in winter period, and in summer, however, maize silage and brought pasture forage from grasses and papilionaceous plants. All the analyses were made only in those milk samples in which the somatic cell count did not exceed $400000 \mathrm{cell} / \mathrm{ml}$, i.e. samples which were collected from the cows with healthy udder.

In each milk sample, there was determined a content of fat, protein and dry matter (Infrared Milk Analyzer Bentley 150), percentage of fat globules sized $<6 \mu \mathrm{m}, 6-10 \mu \mathrm{m}$ and $>10 \mu \mathrm{m}$ (by microscope at $\times 1000$ magnification in the Sudan-III stain preparations).

In part of milk samples there was also established a fatty acids profile using the gas chromatography Varian CG 3900 instrument fitted with flame ionization detector (FID) and capillary pillar CP Sil 88 with Star GS Workstation ver. 5.5 application. The milk samples for these determinations were prepared in compliance with AOAC 969.33.2000 and AOAC 963.22.2000. The analysis covered the following fatty acids groups:

- saturated (SFA), in that short- and medium chain (SFAsc) and long chain (SFAIC),

- unsaturated (UFA), in that monounsaturated (MUFA) and polyunsaturated (PUFA) as well as isomers of conjugated linoleic acid (CLA).

A ratio between the above mentioned acids SFA:UFA, MUFA:SFA and PUFA:SFA was computed.

In statistical analysis the following factors were taken into consideration:

1. cows breed (Simmental, Polish Holstein-Friesian Red-White variety and Polish Holstein-Friesian Black-White variety)

2. production season which was associated with feeding system:

a. summer (samples were collected from the first half of May to the end of July)

b. winter (from the end of November to the end of February),

using the following linear model:

$$
Y_{i j k}=\mu+G_{i}+S_{j}+e_{i j k}
$$

where is $Y_{i j k}$ the trait value, $\mu$ the general average, $G_{i}$ the cows breed $(i=1 \ldots 3), S_{j}$ the feeding season $(j=1,2)$ and $e_{i j k}$ the deviation.

The obtained results were analyzed statistically using STATISTICA ver. 6 program (StatSoft Inc. 2003) on the grounds of two-factor (breed and feeding season) analysis of variance with interaction; the mean values for each characteristics and standard deviation were given. Significance of differences between the mean values for the investigated groups was established with Fisher's LSD test.

\section{Results}

The data presented in Table 1 reveal that the cows Simmental breed produced milk of the highest content of fat, protein $(P \leq 0.01)$, dry matter $(P \leq 0.01)$ and at the same time the most advantageous protein:fat ratio $(P \leq 0.01)$ as compared to the Polish Holstein-Frisian 
Black-White and Red-White variety. It was also shown that the milk of Simmentalers was characterized with a significantly higher $(P \leq 0.01)$ percentage of big-sized fat globules $(8.21 \%)$ as against the Black-White cows $(6.63 \%)$ and Red-White $(5.44 \%)$. The HolsteinFrisian cows of both varieties produced milk of a higher (over $70 \%$ ) share of small-sized fat globules in relation to Simmentalers (67.59\%).

The milk gained in winter had a higher concentration of the basic constituents $(P \leq 0.01)$ with, as a rule, a less advantageous protein:fat ratio recorded at that time. A percentage of big-sized fat globules $(>10 \mu \mathrm{m})$ appeared to be clearly higher compared to the summer period, that is nearly four times higher in Simmental breed and Polish Holstein-Frisian Red-White variety cows and about twice in Black-White variety (Table 1).

Table 1

Content of fat, protein and dry matter in milk and state of milk fat dispersion from 3 breeds of cows in relation to production season ( $\overline{\mathrm{x}} \pm \mathrm{SD})$

Milchinhaltstoffe und Größe der Fettkügelchen in der Sommer- und Wintersaison

\begin{tabular}{|c|c|c|c|c|c|c|c|c|c|}
\hline \multirow[b]{2}{*}{ Breed } & \multirow{2}{*}{$\begin{array}{l}\text { Feeding } \\
\text { season }\end{array}$} & \multirow[b]{2}{*}{$n$} & \multirow[b]{2}{*}{ Fat, \% } & \multirow[b]{2}{*}{ Protein, \% } & \multirow[b]{2}{*}{$P: F$ ratio } & \multirow[b]{2}{*}{ Dry matter, $\%$} & \multicolumn{3}{|c|}{ Fat globules share, \% } \\
\hline & & & & & & & $\begin{array}{l}\text { small } \\
(<6 \mu \mathrm{m})\end{array}$ & $\begin{array}{c}\text { medium } \\
(6-10 \mu \mathrm{m})\end{array}$ & $\begin{array}{c}\text { big } \\
(>10 \mu \mathrm{m})\end{array}$ \\
\hline \multirow{6}{*}{ Simmental } & \multirow{2}{*}{ summer } & \multirow{2}{*}{55} & $4.11^{x x}$ & $3.61^{x}$ & 0.89 & $13.29^{x x}$ & $73.11^{x x}$ & 23.92 & $2.98^{x}$ \\
\hline & & & 0.57 & 0.41 & 0.10 & 0.82 & 4.73 & 3.99 & 2.11 \\
\hline & \multirow{2}{*}{ winter } & \multirow{2}{*}{82} & $4.51^{x x}$ & $4.04^{x}$ & 0.89 & $13.89^{x x}$ & $63.88^{x x}$ & 24.69 & $11.72^{x}$ \\
\hline & & & 0.60 & 0.47 & 0.45 & 1.03 & 11.64 & 7.40 & 7.12 \\
\hline & \multirow{2}{*}{ together } & \multirow{2}{*}{137} & 4.36 & $3.88^{\mathrm{A}}$ & $0.89^{\mathrm{A}}$ & $13.67^{\mathrm{A}}$ & $67.59^{A}$ & $24.38^{A}$ & $8.21^{\mathrm{A}}$ \\
\hline & & & 0.62 & 0.41 & 0.16 & 0.02 & 10.50 & 6.25 & 7.10 \\
\hline \multirow{6}{*}{$\begin{array}{l}\text { Polish } \\
\text { Holstein- } \\
\text { Frisian } \\
\text { Red-White } \\
\text { variety }\end{array}$} & \multirow{2}{*}{ summer } & \multirow{2}{*}{43} & $3.88^{x x}$ & 3.43 & $0.89^{x x}$ & $12.85^{x x}$ & $70.46^{x x}$ & $27.18^{x x}$ & $1.89^{x x}$ \\
\hline & & & 0.63 & 0.46 & 0.10 & 0.94 & 6.00 & 6.39 & 2.05 \\
\hline & \multirow{2}{*}{ winter } & \multirow{2}{*}{77} & $4.48^{x x}$ & 3.58 & $0.81^{x x}$ & $13.35^{x x}$ & $74.76^{x x}$ & $17.82^{x x}$ & $7.42^{x x}$ \\
\hline & & & 0.71 & 0.49 & 0.10 & 1.08 & 8.08 & 5.67 & 3.44 \\
\hline & \multirow{2}{*}{ together } & \multirow{2}{*}{120} & 4.30 & $3.53^{\mathrm{B}}$ & $0.83^{\mathrm{B}}$ & $13.20^{\mathrm{B}}$ & $73.22^{\mathrm{B}}$ & $21.17^{\mathrm{B}}$ & $5.44^{\mathrm{B}}$ \\
\hline & & & 0.74 & 0.48 & 0.11 & 1.06 & 7.66 & 7.43 & 4.01 \\
\hline \multirow{6}{*}{$\begin{array}{l}\text { Polish } \\
\text { Holstein- } \\
\text { Frisian } \\
\text { Black-White } \\
\text { variety }\end{array}$} & \multirow{2}{*}{ summer } & \multirow{2}{*}{108} & 4.16 & 3.37 & 0.82 & 12.90 & $75.63^{x x}$ & 20.40 & $4.14^{\mathrm{xx}}$ \\
\hline & & & 0.70 & 0.38 & 0.12 & 0.91 & 5.17 & 4.63 & 2.76 \\
\hline & \multirow{2}{*}{ winter } & \multirow{2}{*}{150} & 4.41 & 3.43 & 0.79 & 13.21 & $69.97^{x x}$ & 22.25 & $7.76^{\mathrm{xx}}$ \\
\hline & & & 0.76 & 0.48 & 0.11 & 1.03 & 8.80 & 7.50 & 3.12 \\
\hline & \multirow{2}{*}{ together } & \multirow{2}{*}{258} & 4.29 & $3.40^{\mathrm{B}}$ & $0.81^{\mathrm{B}}$ & $13.06^{\mathrm{B}}$ & $71.73^{B}$ & $21.67^{B}$ & $6.63^{\mathrm{B}}$ \\
\hline & & & 0.74 & 0.43 & 0.11 & 0.99 & 8.26 & 6.78 & 3.44 \\
\hline \multicolumn{3}{|l|}{$\begin{array}{l}\text { Influence of } \\
\text { breed }\end{array}$} & $* *$ & $* *$ & $* *$ & $* *$ & $* *$ & $* *$ & $* *$ \\
\hline \multicolumn{2}{|c|}{ feeding season } & & ** & * & ** & ** & $* *$ & * & $* *$ \\
\hline \multicolumn{2}{|c|}{$\begin{array}{l}\text { interactions breed } \times \\
\text { feeding season }\end{array}$} & & $* *$ & $* *$ & $* *$ & $* *$ & $* *$ & $* *$ & $* *$ \\
\hline
\end{tabular}

It has been stated that the breed significantly influenced on the all analyzed milk quality traits $(P \leq 0.01)$. The season as well significantly affected on these traits $(P \leq 0.01)$, however in the lowest level on the protein content and size of the medium fat globules share $(P \leq 0.05)$. Moreover, significant interactions between cows breed and production season $(P \leq 0.01)$ for the all traits have been indicated (Table 1). 
The data presented in Table 2 show that the highest SFA share was recorded in the milk from Black-White variety cows $(68.58 \%)$ and the significantly lowest in the Simmentalers $(63.43 \%)$. The significantly highest $(P \leq 0.01)$ percentage of SFAsc was detected in the milk from Black-White variety (18.74\%). Besides, it was demonstrated that the milk from RedWhite and Black-White variety cows contained the highest amount of SFAlc.

Table 2

Fatty acid profile of fat milk of cows from 3 breeds in relation to production season ( $\bar{x} \pm S D)$

Fettsäureprofil des Milchfettes in der Sommer- und Wintersaison

\begin{tabular}{|c|c|c|c|c|c|c|c|c|c|c|c|c|}
\hline \multirow{2}{*}{ Breed } & \multirow{2}{*}{$\begin{array}{l}\text { Feeding } \\
\text { season }\end{array}$} & \multirow{2}{*}{$n$} & \multicolumn{10}{|c|}{ Fatty acids, $\%$} \\
\hline & & & SFAsc & SFAlc & SFA & MUFA & PUFA & UFA & SFA:UFA & MUFA:SFA & PUFA:SFA & CLA \\
\hline \multirow{6}{*}{ Simmental } & \multirow{2}{*}{ summer } & \multirow{2}{*}{32} & 16.01 & $44.94^{x x}$ & $61.01^{x x}$ & $34.17^{x}$ & $4.00^{x x}$ & $38.17^{x x}$ & $1.60^{\mathrm{xx}}$ & $0.56^{x}$ & $0.07^{x x}$ & $0.51^{x}$ \\
\hline & & & 2.66 & 2.35 & 3.18 & 3.51 & 1.15 & 3.45 & 0.22 & 0.08 & 0.04 & 0.20 \\
\hline & \multirow{2}{*}{ winter } & \multirow{2}{*}{46} & 16.36 & $48.27^{x x}$ & $64.63^{x x}$ & $31.62^{x}$ & $2.91^{x x}$ & $34.53^{x x}$ & $1.92^{\mathrm{xx}}$ & $0.50^{x}$ & $0.05^{x x}$ & $0.36^{x}$ \\
\hline & & & 3.67 & 2.76 & 4.42 & 4.41 & 0.75 & 4.49 & 0.38 & 0.11 & 0.01 & 0.18 \\
\hline & \multirow{2}{*}{ together } & \multirow{2}{*}{78} & $16.30^{\mathrm{A}}$ & $47.13^{A}$ & $63.43^{\mathrm{A}}$ & $32.46^{\mathrm{A}}$ & $3.28^{A}$ & $35.74^{\mathrm{A}}$ & $1.81^{\mathrm{a}}$ & $0.52^{\mathrm{A}}$ & $0.05^{\mathrm{A}}$ & $0.44^{\mathrm{A}}$ \\
\hline & & & 3.23 & 3.14 & 4.42 & 4.24 & 1.10 & 4.54 & 0.37 & 0.10 & 0.10 & 0.20 \\
\hline \multirow{6}{*}{$\begin{array}{l}\text { Polish } \\
\text { Holstein- } \\
\text { Frisian } \\
\text { Red-White } \\
\text { variety }\end{array}$} & \multirow{2}{*}{ summer } & \multirow{2}{*}{14} & 16.32 & $47.31^{x}$ & 63.63 & 32.28 & 3.34 & 35.62 & 1.81 & 0.51 & 0.05 & $0.27^{x x}$ \\
\hline & & & 3.18 & 1.64 & 3.42 & 3.28 & 0.44 & 3.49 & 0.30 & 0.08 & 0.01 & 0.07 \\
\hline & \multirow{2}{*}{ winter } & \multirow{2}{*}{52} & 16.82 & $50.65^{x}$ & 67.47 & 28.80 & 3.14 & 31.94 & 2.18 & 0.43 & 0.05 & $0.41^{x x}$ \\
\hline & & & 3.81 & 3.53 & 4.96 & 4.77 & 0.69 & 4.95 & 0.45 & 0.11 & 0.01 & 0.13 \\
\hline & \multirow{2}{*}{ together } & \multirow{2}{*}{66} & $16.71^{\mathrm{A}}$ & $49.94^{B}$ & $66.65^{\mathrm{B}}$ & $29.54^{B}$ & $3.19^{A}$ & $32.72^{\mathrm{B}}$ & $2.10^{\mathrm{b}}$ & $0.45^{\mathrm{B}}$ & $0.05^{A}$ & $0.38^{A}$ \\
\hline & & & 3.64 & 3.49 & 4.89 & 4.68 & 0.64 & 4.87 & 0.45 & 0.11 & 0.01 & 0.13 \\
\hline \multirow{6}{*}{$\begin{array}{l}\text { Polish } \\
\text { Holstein- } \\
\text { Frisian } \\
\text { Black-White } \\
\text { variety }\end{array}$} & \multirow{2}{*}{ summer } & \multirow{2}{*}{52} & 19.37 & $48.79^{x}$ & 68.15 & 28.44 & 2.84 & 31.28 & 2.19 & 0.42 & 0.04 & 0.55 \\
\hline & & & 3.65 & 3.51 & 4.57 & 4.20 & 0.85 & 4.52 & 0.54 & 0.09 & 0.01 & 0.26 \\
\hline & \multirow{2}{*}{ winter } & \multirow{2}{*}{115} & 18.41 & $50.33^{x}$ & 68.74 & 28.13 & 2.58 & 30.71 & 2.31 & 0.42 & 0.04 & 0.51 \\
\hline & & & 3.73 & 3.58 & 4.93 & 4.50 & 0.70 & 4.85 & 0.49 & 0.10 & 0.01 & 0.19 \\
\hline & \multirow{2}{*}{ together } & \multirow{2}{*}{167} & $18.74^{\mathrm{B}}$ & $49.83^{B}$ & $68.58^{C}$ & $28.20^{\mathrm{B}}$ & $2.65^{\mathrm{B}}$ & $30.85^{c}$ & $2.27^{\mathrm{b}}$ & $0.42^{\mathrm{B}}$ & $0.04^{B}$ & $0.53^{B}$ \\
\hline & & & 3.70 & 3.71 & 4.78 & 4.38 & 0.79 & 4.72 & 0.52 & 0.10 & 0.01 & 0.23 \\
\hline \multicolumn{3}{|l|}{$\begin{array}{l}\text { Influence of } \\
\text { breed }\end{array}$} & $* *$ & $* *$ & $* *$ & $* *$ & $* *$ & $* *$ & $*$ & $* *$ & $* *$ & $* *$ \\
\hline \multicolumn{3}{|c|}{ feeding season } & ns & $* *$ & $* *$ & * & $* *$ & $* *$ & $* *$ & $* *$ & $* *$ & ns \\
\hline \multicolumn{3}{|c|}{$\begin{array}{l}\text { interactions breed } \times \\
\text { feeding season }\end{array}$} & ns & ns & ns & ns & $*$ & ns & ns & ns & $* *$ & * \\
\hline
\end{tabular}

FA fatty acids, SFAsc short- and medium-chain saturated FA, SFAlc long-chain saturated FA, SFA saturated FA, MUFA monounsaturated FA, PUFA polyunsaturated FA, UFA unsaturated FA, CLA conjugated linoleic acid $a, b, A, B, C$ differences between breeds, significant at $P \leq 0.01,{ }^{x, x x}$ differences between feeding season within breed, significant at ${ }^{\times \times} P \leq 0.01, \times P \leq 0.05, \quad{ }^{*}, * *$ factor influence significant at ${ }^{*} P \leq 0.01,{ }^{*} P \leq 0.05$, ns not significant

In the Simmentalers' milk, these acids share was lower by nearly $2 \%(P \leq 0.01)$, while a UFA content proved the highest (35.74\%), in that PUFA (3.28\%). It is noteworthy that this milk displayed the most beneficial SFA:UFA ratio $1.81(P \leq 0.05)$ and MUFA:SFA 0.52 and PUFA:SFA $0.05(P \leq 0.01)$. The significantly lowest percentage of UFA, in that PUFA, was recorded in the milk from black-white variety cows, i.e. 30.85 and $2.65 \%(P \leq 0.01)$. This milk also showed a significantly lowest beneficial ratio of the following fatty acids: SFA:UFA 2.27, MUFA:SFA 0.42, PUFA:SFA 0.04. Among the polyunsaturated fatty acids, a group of the isomers of CLA is considered to have the broadest spectrum of benefits for human health. Its highest content was detected in the milk from Black-White variety $(0.53 \%)$, whereas the lowest in the Red-White $(0.38 \%)(P \leq 0.01)$. The data presented in Table 2 show that milk gained in the summer period (when cows were supplied with pasture forage) had a higher share of SFAsc by $0.26 \%$ and the unsaturated by $2.31 \%$, in 
that polyunsaturated by $0.51 \%$. These two last differences were statistically significant $(P \leq 0.01)$. At this period some more advantageous ratio was noted for SFA:UFA, MUFA:SFA and PUFA:SFA $(P \leq 0.01)$.

The statistically significant differences in the profile of milk fat fatty acids among analyzed seasons were showed mainly at Simmental cows breed. It probably resulted from higher differences between the summer and winter nourishment in the farm maintaining this cows breed, in comparison to two remaining. The data contained in Table 2 show that statistically significant interactions (race $\times$ feeding season) were affirmed only for the share of PUFA, in this CLA, $(P \leq 0.05)$ as well as the proportion of PUFA:SFA $(P \leq 0.01)$.

\section{Discussion}

The earlier studies (BARŁOWSKA et al. 2006b, BARŁOWSKA and LITWINCCZUK 2006) have also exhibited that the Simmentalers produced milk of a more favourable protein:fat ratio as compared to the Holstein-Friesian cows. It was confirmed that the milk obtained from the cows Simmental breed showed a significantly higher $(P \leq 0.01)$ percentage of fat globules. CZERNIEWICZ et al. (2006) analyzing fat dispersion in milk from the cows of Holstein-Friesian and Jersey found that a mean diameter of fat globules was 6.19 and $7.68 \mu \mathrm{m}$, respectively.

Bigger diameters of fat globules in raw milk in winter were reported by MICHALSKI et al. (2004). WIKING et al. (2004) hold that progressing daily fat yield increases fat globules diameters as was confirmed in the present studies to some extent.

The present results in Table 2 are consistent with those obtained earlier by the authors (BARŁOWSKA et al. 2006a). JAWORSKI et al. (1995) claim that milk fat originating in the milk from Black-White cows variety was characterized by a significantly higher concentration of the SFA as compared to milk fat recorded in the Polish Red breed cows' milk. CARROLL et al. (2006) estimating a fatty acid level in milk from three breeds of cows (Holstein, Jersey and Brown Swiss) found that Jersey's milk contained most short- and mediumchain acids, whereas Holstein's milk most mono- and polyunsaturated ones. The highest level of C18:2 cis9 and trans11 was recorded in composition of milk from Brown Swiss breed cows. REKLEWSKA and BERNATOWICZ (2003) analyzing milk CLA content showed that its share in total amount of fatty acids is dependent on a breed. The highest CLA level was stated in the milk from Black-White variety (from $7.1 \mathrm{mg} / \mathrm{g}$ fat in autumn up to $11.7 \mathrm{mg} / \mathrm{g}$ in spring) and the lowest in the Simmentalers (from $7.0 \mathrm{mg} / \mathrm{g}$ fat in autumn to $9.4 \mathrm{mg} / \mathrm{g}$ in spring).

Most research works (NAŁĘCZ-TARWACKA et al., 2003; REKLEWSKA et al. 2003, BARŁOWSKA et al. 2006a, NAŁĘCZ-TARWACKA and GRODZKI 2005) emphasize that nutrition is one of the key determinants of fatty acids level and ratio in milk. REKLEWSKA et al. (2003) estimating a content of 8 bioactive fatty acids in milk from the cows fed according to the total mixed ratio (TMR) feeding system and pasture grazed, confirmed a significant higher $(P \leq 0.01)$ content of five acids (C 18:1 t11; C 18:2 c9 t11; C 18:3; C 20:4; C 20:5) in the milk of cows that grazed pasture grass. NAŁĘCZ-TARWACKA et al. (2003) evaluated the effect of a $5 \mathrm{~kg} /$ day carrot dietary additive for Black-White variety cows with $50-70 \%$ HolsteinFriesian genes. It was found that the cows fed in this way produced milk of a lower (by $2.55 \mathrm{~g} / 100 \mathrm{~g}$ fat) SFA content and a higher MUFA level (by $1.04 \mathrm{~g} / 100 \mathrm{~g}$ fat) as well as PUFA (by $0.8 \mathrm{~g} / 100 \mathrm{~g}$ fat) compared to the control. 
Regarding the obtained research results, it may be stated that milk from Holstein-Friesian cows contains fat of a higher dispersion level and a higher percentage of SFAsc. Therefore, it is good material for consumable milk and fermented milk drinks. Simmentalers' milk, though, constitutes better material for hard cheeses and butter production. This fact results from a higher protein:fat ratio and a lower dispersion level of fat. This milk, owing to a higher content of PUFA, shows better dietary properties and ensures effective spreading. Cows feeding with pasture forage in the summer period (independently on breed) have a beneficial impact on an increase of PUFA content in milk.

\section{Acknowledgements}

This work was conducted as part of Ministry of Science and Higher Education project no. N311 014 31/0649.

\section{References}

AOAC (2000) Official Methods of Analysis of the AOCA 963.22. Methyl esters of fatty acids in oils and fats. 17 th ed. Arlington, Virginia, USA

AOAC (2000) Official Methods of Analysis of the AOCA 969.33. Fatty acids in oils and fatty. 17th ed. Arlington, Virginia, USA

Banni S (2002) Conjugated linoleic acid metabolism. Curr Opin Lipidol 13, 261-6

Barłowska J, Litwińczuk Z (2006) Technological usefulness of milk from two local breeds maintained in the regions with great grassland share. Arch Tierz $49 \mathrm{SI}, 207-13$

Barłowska J, Litwińczuk Z, Król J, Kędzierska-Matysek M (2006a) Fatty acid profile and mineral content in milk from cows of various breeds over spring-summer feeding period. Pol J Food Nutr Sci 15/56, 13-16

Barłowska J, Litwińczuk Z, Król J, Topyła B (2006b) Technological usefulness of milk of cows of six breeds maintained in Poland relative to a lactation phase. Pol J Food Nutr Sci, 15/56, 17-21

Carroll SM, Depeters EJ, Taylor SJ, Rosenberg M, Perez-Monti H, Capps VA (2006) Milk composition of Holstein, Jersey, and Brown Swiss cows in response to increasing levels of dietary fat. Anim Feed Sci Technol 131, 451-73

Czerniewicz M, Kiełczewska K, Kruk A (2006) Comparison of some physicochemical properties of milk from Holstein-Friesian and Jersey cows. Pol J Food Nutr Sci, 15/56, 17-21

Goudédranche H, Fauquant J, Maubois JL (2000) Fractionation of globular milk fat by membrane microfiltration. Le lait 80, 93-8

Jaworski J (1995) Composition of the milk fat - the environmental conditionings. Proc of Scientific Conference »Milk fat in human nutrition«, ART. Olsztyn 22-23 September 1995, 5-19

Jensen RG (2002) The composition of bovine milk lipids. January 1995 to December 2000. J Dairy Sci 85, 295-350

Kozikowski W, Przybyłowicz K (1994) Feeding value of the components of cow's milk. Pol Dairy J 10, 256-61

Lawless F, Stanton C, L'Escop P, Devery R, Dillon P, Murphy JJ (1999) Influence of breed on bovine milk cis-9, trans-11-conjugated linoleic acid content. Livest Prod Sci 62, 43-9

Michalski MC, Gassi JY, Famelard MH, Leconte N, Camier M, Michel F, Briard V (2003) The size of native milk fat globules affect phycico-chemical and sensory properties of Camembert cheese. Le lait 83, 131-43

Michalski MC, Januel C (2006) Does homogenization affect the human health properties of cow's milk? Trends in Ford Sci \& Tech 17, 423-37

Michalski MC, Michel F, Sainmont D, Briard V (2002) On the size distribution and zeta-potential of homogenized milk fat globules. In: Anton M (red), Food Emulsions and Dispersions. Research Signpost, Kerala, India, 49-65

Michalski MC, Ollivon M, Briard V, Leconte N, LOPEZ C (2004) Native fat globules of different sizes selected from raw milk: thermal and structural behavior. Chem Phys Lip 132, 247-61

Nałęcz-Tarwacka T, Grodzki H (2005) Influence of early spring feeding of fatty acid levels of cow's milk. Pol J Food Nutr Sci, 14/55, 67-70 
Nałęcz-Tarwacka T, Karaszewska A, Dziarski K (2003) The influence of carrot addition to cow's ration on the level of vitamins and fatty acids in cow milk. Pol J Food Nutr Sci, 12/53, 53-6

Palmquist DL, Beaulieu AD, Barbano DM (1993) Feed and animal factors influencing milk fat composition. J Dairy Sci 76, 1753-71

Park Y, Albright KJ, Liu W, Storkson JM, Cook ME, Pariza MW (1997) Effect of conjugated linoleic acid on body composition in mice. Lipids 32, 853-8

Parodi PW (2004) Milk fat in human nutrition. Austral Dairy Techn 59, 3-59

Reklewska B, Bernatowicz E (2003) Milk functional components - significance for the organism and possibilities for modifying their level in the milk of cows. Appl Sci Rep of Anim Prod Review 71, 47-69

Reklewska B, Bernatowicz E, Reklewski Z, Nałęcz-Tarwacka T, Kuczyńska B, Zdziarski K, Oprządek A (2003) Concentration of milk functional components in Black-and-White cows, depending on the season and feeding system. Appl Sci Rep of Anim Prod Review 68, 85-98

Reklewski Z (2000) Improvement of health-promoting values of milk - the effect of feeding on the fat quality and cholesterol level. Appl Sci Rep of Anim Prod Review 51, 27-39

Pfeuffer M (2001) Physiologic effects of individual fatty acids in animal and human body with particular attention to conary heart disease risk modulation. Arch Tierz 44, 89-98

Seifert MF, Watkins BA (1997) Role in dietary lipid and antioxidants in bone metabolism. Nutr Res 17, $1209-28$

STATSOFT Inc (2003) Statistica (data analysis software system) ver. 6

Walisiewicz-Niedbalska W, Patkowska-Sokoła B, Bodkowski R, Różycki K (2004) The influence of linolic acid and its isomers in goat diet on the composition of fatty acid in goat milk fat. Arch Tierz $46 \mathrm{SI}$, 103-7

Wiking L, Stagsted J, Björck L, Nielsen JH (2004) Milk fat globule size is affected by fat production in dairy cows. Intern Dairy J 14, 909-13

Żegarska Z (1998) Milk fat as the component of the man's diet. Pol Dairy J 10, 369-71

Received 21 July 2008, accepted 30 March 2009.

Corresponding author:

Dr. hab. JOANNA BARŁOWSKA

email: joanna.barlowska@up.lublin.pl

Department of Commodity Science and Processing of Animal Raw Materials, University of Life Sciences in Lublin, ul. Akademicka 13, 20-950 Lublin, Poland 